\title{
Peranan Mata Kuliah Micro teaching Terhadap Pelaksanaan Praktek Lapangan Kependidikan Bidang Studi Pendidikan Jasmani Kesehatan Dan Rekreasi
}

\author{
Umi Anifah ${ }^{1}$, Madri $\mathbf{M}^{2}$, Windo Wiria Dinata ${ }^{3}$ \\ ${ }^{123}$ Fakultas Ilmu Keolahragaan, Universitas Negeri Padang, Indonesia. \\ E-mail: umi@gamail.com¹,madri.m@fik.unp.ac.id ${ }^{2}$, windowiria@,fik.unp.ac.id
}

\begin{abstract}
Abstrak
Penelitian ini bertujuan untuk mengetahui peranan mata kuliah micro teaching terhadap pelaksanaan praktek lapangan kependidikan bidang studi Penjas. Penelitian ini tergolong penelitian deskriptif, dengan menggunakan jenis data primer. Subjek dalam penelitian ini adalah mahasiswa yang telah melaksanakan praktek lapangan kependidikan semester januari - juni 2006.

Populasi dalam penelitian ini adalah mahasiswa yang telah melaksanakan praktek lapangan kependidikan semester januari - juni 2006 yang berjumlah 33 orang mahasiswa. Pengambilan sampel dilakukan dengan teknik total sampling. Maka jumlah populasi secara keseluruhan menjadi sample dalam penelitian ini. Penelitian ini termasuk deskriptif karena hanya memaparkan gejala semata yaitu peranan mata kuliah micro teaching terhadap pelaksanaan praktek lapangan kependidikan.. Pengumpulan data menggunakan skala likert yang telah disesuaikan.

Untuk menjawab pertanyaan penelitian maka penulis menggunakan langkah - langkah yaitu pertama penyebaran angket, kedua pengumpulan angket serta menganalisis data. Dalam melakukan analisis data peneliti menggunakan teknik analisis deskriptif dengan rumus persentase. Sehingga setelah dianalisis secara keseluruhan dari semua sub variabel yang di paparkan pada pembahasan dapat diketahui bahwa, mahasiswa yang mengatakan peranan micro teaching terhadap pelaksanaan praktek lapangan kependidikan, 82,22\% mahasiswa mengatakan peranannya sangat baik, $13 \%$ mahasiswa mengatakan peranannya baik, $13 \%$ mahasiswa mengatakan peranannya sedang, 4,78\% mahasiswa mengatakan peranannya kurang, Kemudian setelah dicari dengan rumus tabulasi frekuensi maka diketahui, bahwa Mata Kuliah Micro teaching Tehadap Pelaksanaan praktek lapangan kependidikan sangat baik.

Dari hasil penelitian maka penulis mengambil kesimpulan bahwa Mata Kuliah Micro teaching sangat berperan sekali terhadap pelaksanaan Praktek Lapangan Kependidikan, yang tak lepas dari peranan dosen micro teaching dalam menyampaikan materi, membimbing, dan mengevaluasi, serta pelaksanaan pengajaran micro dan pelaksanaan praktek lapangan kependidikan itu sendiri. Ini semua dilakukan untuk keberhasilan mahasiswa dalam melaksanakan praktek lapangan kependidikan disekolah latihan.
\end{abstract}

Kata Kunci: Micro teaching, Praktek Lapangan Kependidikan, Pendidikan Jasmani, Pendidikan Kesehatan, Pendidikan Rekreasi

\begin{abstract}
This study aims to determine the role of micro teaching courses in the implementation of educational field practice in Physical Education. This research is classified as descriptive research, using primary data types. The subjects in this study were students who had carried out educational field practice in the January - June semester of 2006.
\end{abstract}


Sport Science: Jurnal Sain Olahraga dan Pendidikan Jasmani ISSN 114-562X (Cetak), ISSN XXXX-XXXX(Online)

http://sportscience.ppj.unp.ac.id/index.php/jss/index

The population in this study were students who had carried out educational practice in the semester of January - June 2006, totaling 33 students. Sampling is done by total sampling technique. Then the total population as a sample in this study. This research is descriptive because it only describes the symptoms of the role of micro teaching courses in the implementation of educational field practice. Data collection uses a Likert scale that has been adjusted.

To answer the research question, the authors use the steps - first, questionnaire distribution, secondly questionnaire collection and data analysis. In analyzing the data the researchers used a descriptive analysis technique with a percentage formula. So that after overall analysis of all the sub variables explained in the discussion it can be seen that, students who said the role of micro teaching in the implementation of educational field practice, $82.22 \%$ of students said their role was very good, $13 \%$ of students said their role was good, $13 \%$ of students said their role was moderate, $4.78 \%$ of students said their role was lacking, Then after searching for the formula of frequency tabulation it was known, that the Micro teaching Subjects Subject to the Implementation of educational field practice was very good.

From the results of the study, the authors conclude that Micro teaching Course is very instrumental in the implementation of Educational Field Practice, which cannot be separated from the role of micro teaching lecturers in delivering material, guiding, and evaluating, as well as the implementation of micro teaching and the implementation of educational field practice itself. This is all done for the success of students in carrying out educational field practice in training schools.

Keywords: Micro teaching, Educational Field Practice, Physical Education, Health Education, Recreational Education

\section{PENDAHULUAN}

Kualitas pendidikan sangat tergantung pada kemampuan guru dalam melaksanakan proses belajar mengajar. Betapapun hebatnya penyusunan kurikulum, canggihnya media yang digunakan, lengkapnya fasilitas yang tersedia, tanpa guru yang berkualitas, maka tidak akan membawa hasil yang optimal dalam melaksanakan PBM. Dalam UU RI No.14 Tahun 2005, bahwa guru adalah pendidik profesional dengan tugas utama mendidik, mengajar, membimbing, mengarah, melatih, menilai dan mengevaluasi peserta didik pada pendidikan anak usia dini, jalur pendidikan formal, pendidikan dasar dan pendidikan menengah.

Oleh karena itu, Universitas Negeri Padang terus berupaya menghasilkan lulusan yang profesional di bidangnya serta tenaga kependidikan yang berkualitas. Untuk mewujudkan tujuan diatas, khususnya di Fakultas Ilmu Keolahragaan Universitas Negeri Padang selain membekali mahasiswa dengan perkuliahan teori, mahasiswa juga dibekali dengan pengalaman nyata yang dilakukan di luar bangku perkuliahan yaitu melalui Praktek Lapangan Kependidikan (PLK) yang merupakan mata kuliah wajib untuk jenjang program strata satu (S1) dan Diploma 2 (D2) Penjas di Fakultas Ilmu Keolahragaan pada program kependidikan.

Pada jurusan pendidikan jasmani dan kesehatan dengan melalui Praktek Lapangan Kependidikan (PLK) diharapkan mahasiswa dapat mengaplikasikan ilmu yang diperoleh pada bangku perkuliahan. Oleh karena itu, agar mahasiswa jurusan pendidikan jasmani dan kesehatan Fakultas Ilmu Keolahragaan Universitas Negeri Padang benar-benar siap terjun kelapangan pendidikan dan berperan sebagai seorang guru di sekolah mitra. Penjelasan tersebut diperkuat oleh pendapat (Asnaldi, 2015)" Seorang guru tidak saja menguasai pelajaran yang diajarkan- tetapi juga mampu datam menanamkan konsep pengetahuan yang diajarkan", maka mata kuliah Praktek Lapangan Kependidikan diikuti oleh mahasiswa yang memenuhi persyaratan yang ditetapkan oleh jurusan bersama koordinator Praktek Lapangan Kependidikan 
Salah satu persyaratannya adalah telah lulus mata kuliah Micro teaching, karena mata kuliah Micro teaching sangat mendukung keberhasilan dalam PLK. Dalam mata kuliah Micro teaching mahasiswa dituntut menguasai 10 kompetensi yang harus dikuasai oleh seorang guru yang dikemukakan oleh Raka Joni, yaitu:

(1) Menguasai bahan ajar, (2) Merencanakan Program Belajar Mengajar (PBM), (3)

Menggunakan media / sarana dan prasarana, (4) Melaksanakan interaksi belajar mengajar,

(5) Mengelola kelas, (6) Evaluasi hasil belajar siswa, (7) Melaksanakan pengajaran remedial, (8) Melaksanakan bimbingan, (9) Menguasai landaasan-landasan pendidikan, (10) Menguasai prinsip-prinsip penafsiran hasil penelitian guru keperluan mengajar.

Dalam Buku Pedoman Pengajaran Micro Tahun 2005 diterangkan bahwa perkuliahan Micro teaching, Mahasiswa dibimbing dan diarahkan oleh dosen mata kuliah micro teaching untuk pengenalan pengajaran micro mulai dari membuka dan menutup pelajaran, praktek pengajaran micro, Observasi, diskusi(Balikan). Dalam latihan mengajar sekolompok mahasiswa (7-8) berlatih bersama dengan bergilir memainkan peran 5 orang sebagai murid, 1 orang sebagai guru, 2 orang sebagai observer. Kemudian diadakan perencanaan ulang, praktek ulang pengajaran, observasi ulang, dan diskusi ulang, supaya mahasiswa calon guru memahami dan mengerti apa yang akan dilakukan seorang guru apabila mengajar nanti di sekolah.

Kenyataannya pada saat perkuliahan micro teaching berlangsung, mahasiswa dibagi beberapa kelompok kecil untuk tampil menjadi guru secara bergantian, dosen pembimbing micro teaching tidak sempat mengawasi dan memberi saran serta kritik pada setiap mahasiswa yang tampil mengajar menjadi guru, sehingga mahasiswa tersebut akan merasa bahwa dia sudah sempurna menjadi guru, apabila praktek lapangan disekolah latihan, namun kenyataannya pada saat mengajar di sekolah latihan mahasiswa belum tahu apa yang akan dilakukan, seharusnya mahasiswa tidak boleh bersikap seperti itu, karena akan merugikan sekolah latihan tersebut.

Pada hakekatnya mata kuliah micro teaching memberikan kontribusi terhadap hasil belajar PLK karena kegiatan-kegiatan yang ditemui dalam PLK sudah dipelajari dalam mata kuliah micro teaching. Sebagaimana yang dikemukakan oleh S.L La Sulo (1984:14) yaitu program praktek mengajar dalam pengajaran mikro (micro teaching) merupakan bagian dari program pengalaman lapangan yang berusaha untuk menimbulkan, mengembangkan serta membina keterampilan tertentu dari calon guru dalam menghadapi kelas. Pada dasarnya kegiatan ini dapat diperoleh mahasiswa dalam melaksanakan PLK dan tergantung kepada mahasiswa yang melaksanakan PLK itu sendiri.

Rumusan belajar pada manusia menurut W.S. Winkel (1984:36) adalah suatu aktifitas mental/psikis yang berlangsung dalam interaksi aktif dengan lingkungan yang menghasilkan perubahan dalam pengetahuan, pemahaman, keterampilan dan nilai sikap. Perubahan itu bersifat secara relatife konstan dan berbekas.

Perubahan-perubahan itu dapat berupa suatu hasil yang baru ataupun penyempurnaan terhadap hasil yang diperoleh. Hasil belajar dapat berupa hasil utama dapat juga berupa hasil sebagai efek samping. Hasil belajar diperoleh seseorang dapat diketahui dari prestasi belajarnya. Berdasarkan hal di atas, maka prestasi belajar dapat diartikan sebagai hasil dari kegiatan mahasiswa yang kondisikan melalui proses belajar mengajar.

\section{METODE}

Mengingat data yang diambil untuk penelitian ini merupakan data yang telah berlalu maka penelitian hanya bersifat deskriptif.deskriptif adalah penelitian yang tidak bermaksud untuk mengkaji hipotesis tertentu, tetapi hanya menggambarkan apa adanya tentang suatu variabel, gejala, atau keadaan. Dalam hal ini adalah gambaran Peranan Mata Kuliah Micro teaching Terhadap Pelaksanaan Praktek Lapangan Kependidikan Semester Januari - Juni 2006 penelitian ini dilaksanakan pada semester januari - juni 2006, penelitian dilaksanakan setelah propsal disetujui dosen pembimbing dan 
Sport Science: Jurnal Sain Olahraga dan Pendidikan Jasmani ISSN 114-562X (Cetak), ISSN XXXX-XXXX(Online)

http://sportscience.ppj.unp.ac.id/index.php/jss/index

dosen penguji di waktu seminar. Sedangkan penelitian ini dilaksanakan di Fakultas Ilmu Keolahragaan Universitas Negeri Padang.

Populasi dalam peneltian ini adalah seluruh Mahasiswa jurusan Penjas FIK UNP yang melaksanakan PLK Semester Januari - Juni 2006 yang berjumlah 33 orang, lebih jelasnya pada tabel di bawah ini:

Tabel 1 : Populasi Penelitian

\begin{tabular}{crcc}
\hline No & BP & Program Studi & Jumlah \\
\hline 1 & 2001 & Penjaskesrek & 12 \\
2 & 2002 & Penjaskeserek & 21 \\
& Jumlah & & 33 \\
\hline
\end{tabular}

Sumber: Data UPPL UNP Tahun 2006

Yang menjadi sampel dalam penelitian ini adalah seluruh mahasiswa jurusan Penjas yang melaksanakan PLK semester Januari - Juni 2006, yang berjumlah 33 orang. Penarikan sampel dalam penelitian ini menggunakan Total Sampling, artinya semua populasi menjadi sampel dalam penelitian ini. Dalam penelitian ini data yang digunakan adalah data primer dan data sekunder. Data primer adalah data yang dikumpulkan langsung oleh peneliti dengan mengajukan angket dan langsung diisi responden yang kemudian di lakukan pengolahan data, dan data sekunder adalah data yang sudah ada dan tidak langsung diambil.

Data sekunder dalam penelitian ini adalah mahasiswa yang terdaftar mengikuti PLk semester Januari-Juni 2006. Sumber data dalam penelitian ini adalah mahasiswa FIK UNP jurusan Penjaskes yang melaksanakan PLK semester januari - juni 2006.

\section{Teknik dan alat Pengumpulan Data}

\section{Teknik pengumpulan data.}

Untuk mengumpulkan data dalam penelitian ini adalah kuisioner (angket) yang digunakan untuk mendapatkan informasi tentang peranan mata kuliah micro teaching terhadap pelaksanaan PLK. Data primer yang diperoleh langsung dari responden melalui daftar pertanyaan berupa angket dengan langkah - langkah sebagai berikut:

a. membuat angket yang disertai dengan pertanyaan.

b. melakukan uji coba angket.

c. menyebarkan angket

d. Pengumpulan angket yang telah diisi.

e. Pengecekan hasil angket.

f. Melakukan pengolahan data.

2. Alat Pengumpulan Data (Instrumen).

Instrumen yang digunakan dalam penelitian ini adalah berupa angket.angket tersebut disusun dengan model skala likert yang dinyatakan oleh Thucam yakni skala yang terdiri dari lima angka dimana interval diantara setiap angka pada skala tersebut diasumsikan sama. Skala ini digunakan untuk mengatur tingkat frekuensi yang sangat tinggi, didasarkan pada asumsi bahwa jawaban yang ada pada skala merupakan ukuran kuantitatif.

Angket yang digunakan adalah angket tertutup, yaitu jawabannya sudah disediakan dan responden tinggal memilih salah satu jawaban alternatif tersebut. Untuk pernyataan positif masing masing diberi skor dengan urutan 5,4,3,2,1. sedangkan untuk pernyataan negatif diberi skor dengan urutan 1,2,3,4,5. dalam angket tersebut ada lima alternatif jawaban yaitu:

1. Sangat setuju (ST) dikualisifikasikan sangat baik (SB)

2. Setuju (S) dikualisifikasikan baik (B)

3. Ragu - ragu (RR) dikualisifikasikan sedang (SD)

4. Tidak setuju (TS) dikualisifikasikan kurang (K)

5. Sangat tidak setuju (STS) dikualisifikasikan kurang (SK) 
Penyusunan kuesioner dilakukan dengan langkah : (1) pembuatan kisi - kisi berdasarkan variabel, (2) menyusun butir - butir pertanyaan, (3) melakukan analisis rasional untuk melihat kesesuaian butir - butir pertanyaan dengan variabel.Setelah angket disebarkan dan dikumpulkan selanjutnya dilakukan pengolahan data berdasarkan angket yang terkumpul dan telah memenuhi syarat untuk analisis, kemudian dilakukan pemberian angka untuk menghitung jumlahnya.

Sudjana (1989:65) menjelaskan bahwa "Skor yang diperoleh setiap responden dapat dihiting dengan memeriksa jawaban yang bersangkutan". Semua data berhasil dikumpulkan dan disusun menurut kelompoknya masing - masing diolah dengan menggunakan teknik distribusi frekuensi atau statistic deskriptif

\section{HASIL DAN PEMBAHASAN Hasil Penelitian}

Pada bab ini akan dibahas dan dikemukakan mengenai hasil penelitian dan pembahasan. Hasil penelitian diperoleh dari angket yang diedarkan kepada responden. Angket yang berisikan pernyataan yang berkenaan dengan pertanyaan penelitian, tentang bagaimana peranan mata kuliah micro teaching terhadap pelaksanaan praktek lapangan kependidikan bidang studi penjas.

Sebelum penelitian dilaksanakan terhadap mahasiswa, terlebih dahulu diadakan uji coba angket. Uji coba angket yang digunakan adalah uji coba terpakai dengan maksud angket yang telah disiapkan akan disetujui pembimbing langsung diberikan pada responden yang langsung diisi oleh responden itu sendiri, untuk melihat hasil keseluruhan angket tersebut langsung diolah dan dibahas secara keseluruhan.

Pelaksanaan penelitian dilaksanakan dengan cara penyebaran angket kepada responden sebanyak 33 orang dari mahasiswa yang telah melaksanakan PLK semester januari - juni 2006 dari jurusan penjaskes. Selanjutnya menyiapkan tabel kerja sebanyak item pernyataan yang diberikan setelah itu dilakukan pengolahan data kedalam tabel frekuensi. Dan setelah itu ditarik kesimpulan berdasarkan kualisifikasi yang telah ditentukan.

\section{Hasil Penelitian}

Hasil penelitian yang sudah diperoleh melalui penyebaran angket kepada sampel maka alternatif jawaban dibagi menjadi tiga kelompok yaitu sangat setuju (SS) dan Setuju (S) dikelompokkan dalam kategori sangat setuju (SS). Kemudian kategori Ragu-Ragu (RR), tidak setuju (TS) dan sangat tidak setuju (STS) dikelompokkan kedalam kategori tidak setuju (TS). Akan ditampilkan bertahap berdasarkan variabel yang diteliti.

\section{Dosen dalam menyampaikan materi micro teaching.}

Sesuai dengan hasil penelitian yang dilakukan maka data tersebut dikelompokan dan dimasukan kedalam sebuah tabel distribusi frekuensi yang dibagi dalam tiga alternative jawaban yaitu sangat setuju (SS), setuju (S), ragu - ragu (RR), untuk lebih jelasnya dapat dilihat pada tabel di bawah ini:

Tabel 2. Tabel Distribusi Frekuensi Dosen Dalam Menyampaikan Materi Micro teaching

\begin{tabular}{ccccccccc}
\hline No. & \multicolumn{2}{c}{ Sangat Setuju } & \multicolumn{2}{c}{ Ragu-Ragu } & \multicolumn{2}{c}{ Tidak Setuju } & \multicolumn{2}{c}{ Jumlah } \\
Item. & F & $\%$ & F & $\%$ & F & $\%$ & F & $\%$ \\
\hline 1. & 31 & 93.9 & 2 & 6.06 & - & - & 33 & 100 \\
2. & 30 & 90.9 & 3 & 9.09 & - & - & 33 & 100 \\
3. & 29 & 87.9 & 1 & 3.03 & 3 & 9.09 & 33 & 100 \\
4. & 29 & 87.9 & 4 & 12.1 & - & - & 33 & 100 \\
5. & 22 & 66.7 & 10 & 30.3 & 1 & 3.03 & 33 & 100 \\
6. & 32 & 97 & 1 & 3.03 & - & - & 33 & 100 \\
7. & 27 & 81.8 & 5 & 15.2 & 1 & 3.03 & 33 & 100 \\
8. & 25 & 75.8 & 6 & 18.2 & 2 & 6.06 & 33 & 100 \\
$\Sigma$ & 225 & 85.22 & 32 & 12.12 & 7 & 2.65 & 264 & 100 \\
\hline
\end{tabular}


Berdasarkan data responden yang telah dimasukan ke dalam tabel distribusi frekuensi diatas maka diperoleh, sebanyak 27 orang atau $85,23 \%$ mahasiswa menyatakan dosen dalam menyampaikan materi micro teaching sudah sangat baik, sebanyak 5 orang atau $12,12 \%$ setuju dan dapat dikualisifikasikan dengan jumlah tersebut termasuk bagus, sebanyak 1 orang atau 2,65\% ragu - ragu dengan jumlah tersebut dapat dikualisifikasikan sedang.

Hasil yang diperoleh dan dimasukan kedalam tabel distribusi frekuensi dikualisifikasikan kedalam tiga jawaban untuk didapat kesimpulan. Untuk lebih jelasnya dapat dilihat dalam tabel berikut ini.

Tabel 3. Klasifikasi Dosen Dalam Menyampaikan Materi Micro teaching

\begin{tabular}{llcc}
\hline No & \multicolumn{1}{c}{ Jawaban } & Jumlah & Persentase(\%) \\
\hline 1 & Sangat baik(SB) & 27 & 85,23 \\
2 & Baik(B) & 5 & 12,12 \\
3 & Sedang(SD) & 1 & 2,65 \\
& Jumlah & 33 & 100 \\
\hline
\end{tabular}

Tabel tersebut digunakan untuk membuat grafik histogram mengenai bagaimana dosen dalam menyampaikan materi micro teaching yaitu:

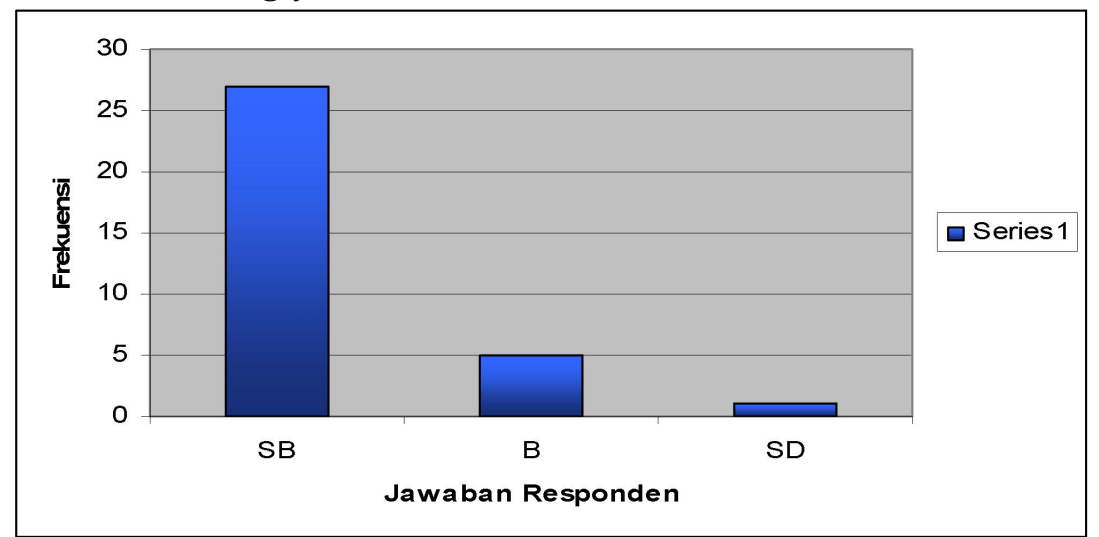

Gambar 1. Grafik Dosen Dalam Menyampaikan Materi Micro teaching

2. Dosen Dalam Melaksanakan Bimbingan Pengajaran Micro teaching.

Sesuai dengan hasil penelitian yang dilakukan maka data tersebut di kelompokan dan dimasukan kedalam sebuah tabel distribusi frekuensi yang dibagi dalam tiga alternatif jawaban yaitu sangat setuju (SS), setuju (S), ragu - ragu (RR). Untuk lebih jelasnya dapat dilihat dalam tabel distribusi.

Tabel 4.. Tabel Distribusi FrekuensiDosen dalam Melaksanakan Bimbingan Pengajaran micro

\begin{tabular}{ccccccccc}
\multicolumn{10}{c}{ teaching } \\
\hline No. & \multicolumn{2}{c}{ Sangat Setuju } & \multicolumn{2}{c}{ Ragu-Ragu } & \multicolumn{2}{c}{ Tidak Setuju } & \multicolumn{2}{c}{ Jumlah } \\
Item. & F & $\%$ & F & $\%$ & F & $\%$ & F & $\%$ \\
\hline 9. & 30 & 90.9 & 2 & 6.06 & 1 & 3.03 & 33 & 100 \\
10. & 24 & 72.7 & 8 & 24.2 & 1 & 3.03 & 33 & 100 \\
11. & 28 & 84.8 & 4 & 12.1 & 1 & 3.03 & 33 & 100 \\
12. & 25 & 75.8 & 7 & 21.2 & 1 & 3.03 & 33 & 100 \\
13. & 27 & 81.8 & 5 & 15.2 & 1 & 3.03 & 33 & 100 \\
$\sum$ & 134 & 81.21 & 26 & 15.76 & 5 & 3.03 & 165 & 100 \\
\hline
\end{tabular}

Berdasarkan data responden yang telah dimasukan kedalam tabel distribusi frekuensi diatas maka diperoleh, sebanyak 25 orang atau $81,21 \%$ sangat setuju sehingga dikualisifikasikan $81,21 \%$ mahasiswa mengakui sangat bagus dosen dalam membimbing pengajaran micro teaching, sebanyak 6 
orang atau $15,76 \%$ setuju dan dikualisifikasikan $15,76 \%$ bagus, sebanyak 2 orang atau 3,03\% raguragu sehingga dikualisifikasikan 3,03\% mahasiswa mengakui dengan nilai sedang. tiga jawaban.

Hasil yang diperoleh dimasukan kedalam tabel distribusi frekuensi dikualisifikasikan kedalam

Tabel 5. Klasifikasi Dosen Dalam Melaksanakan Bimbingan Pengajaran Micro teaching

\begin{tabular}{cccc}
\hline No & Jawaban & jumlah & Persentase(\%) \\
\hline 1 & Sangat baik(SB) & 25 & 81,21 \\
2 & Baik(B) & 6 & 15,76 \\
3 & Sedang(SD) & 2 & 3,03 \\
& Jumlah & 33 & 100 \\
\hline
\end{tabular}

Tabel tersebut dapat digunakan untuk membuat grafik histogram, yaitu :

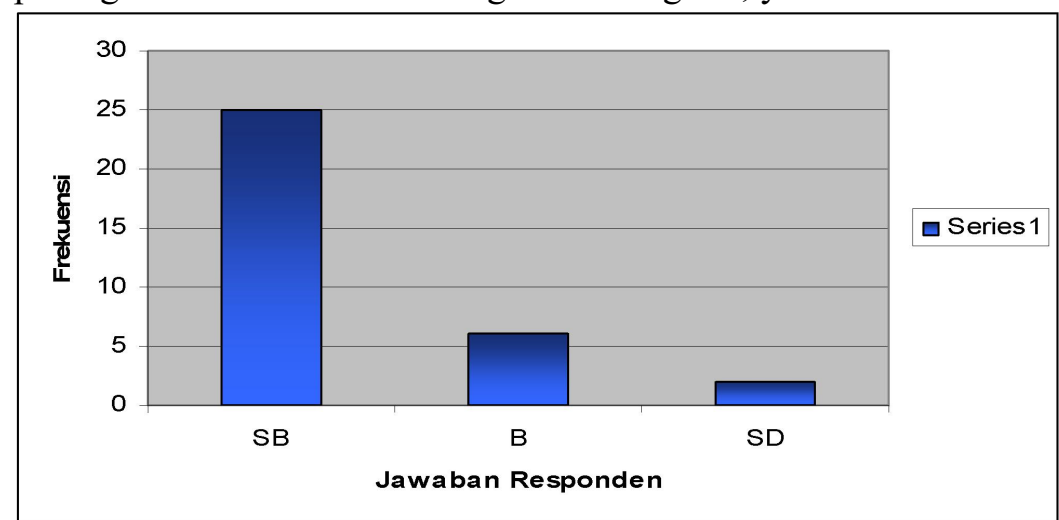

Grafik 2. Dosen Dalam melasanakan bimbingan Pengajaran Micro teaching

\section{Dosen Micro teaching Dalam mengevaluasi Pengajaran.}

Sesuai dengan hasil penelitian yang dilakukan maka data tersebut dikekompokan dan dimasukan kedalam sebuah tabel distribusi frekuensi yang dibagi dalam tiga alternative jawaban yaitu sangat setuju (SS), sejutu (S), ragu- ragu (RR). Untuk lebih jelasnya dapat dilihat dalam tabel distribusi.

Tabel 7. Tabel Distribusi Frekuensi Dosen Micro teaching Dalam Mengevaluasi Pengajaran

\begin{tabular}{ccccccccc}
\hline No. & \multicolumn{2}{c}{ Sangat Setuju } & \multicolumn{2}{c}{ Ragu-Ragu } & \multicolumn{3}{c}{ Tidak Setuju } & \multicolumn{2}{c}{ Jumlah } \\
\hline Item. & F & $\%$ & F & $\%$ & F & $\%$ & F & $\%$ \\
14. & 23 & 69.7 & 7 & 21.2 & 3 & 9.09 & 33 & 100 \\
15. & 28 & 84.8 & 3 & 9.09 & 2 & 6.06 & 33 & 100 \\
16. & 32 & 97 & - & - & 1 & 3.03 & 33 & 100 \\
17. & 7 & 21.2 & 11 & 33.3 & 15 & 45.5 & 33 & 100 \\
18. & 20 & 60.6 & 8 & 24.2 & 5 & 15.2 & 33 & 100 \\
19. & 25 & 75.8 & 5 & 15.2 & 3 & 9.09 & 33 & 100 \\
20. & 28 & 84.8 & 4 & 12.1 & 1 & 3.03 & 33 & 100 \\
21. & 25 & 75.8 & 2 & 6.06 & 6 & 18.2 & 33 & 100 \\
22. & 27 & 81.8 & 3 & 9.09 & 3 & 9.09 & 33 & 100 \\
23. & 28 & 84.8 & 4 & 12.1 & 1 & 3.03 & 33 & 100 \\
$\Sigma$ & 243 & 73.64 & 47 & 14.24 & 40 & 12.1 & 330 & 100 \\
\hline
\end{tabular}

Berdasarkan data responden yang telah dimasukan kedalam tabel distribusi frekuensi diatas maka dapat diperoleh, sebanyak 23 orang atau $73,64 \%$ sangat setuju sehingga dikualisifikasikan $73,64 \%$ dosen micro teaching sangat baik dalam mengevaluasi pembelajaran micro teaching, 
sebanyak 6 orang atau 14,24\% setuju dan dapat dikualisifikasikan baik, sebanyak 4 orang atau 12,12\% ragu- ragu dan dapat dikualisifikasikan sedang.

Hasil yang diperoleh dan dimasukan kedalam tabel distribusi frekuensi dikualisifikasikan kedalam tiga jawaban. Untuk lebih jelasnya dapat dilihat dalam tabel berikut.

Tabel 8. Klasifikasi Dosen Micro teaching Dalam Mengevaluasi Pengajaran

\begin{tabular}{cccc}
\hline No & Jawaban & Jumlah & Persentase(\%) \\
\hline 1 & Sangat baik(SB) & 23 & 73,64 \\
2 & Baik(B) & 6 & 14,24 \\
3 & Sedang(SD) & 4 & 12,12 \\
& Jumlah & 33 & 100 \\
\hline
\end{tabular}

Tabel tersebut digunakan untuk membuat grafik histogram mengenai peranan micro teaching berdasarkan dosen mengevaluasi pembelajaran micro teaching, yaitu:

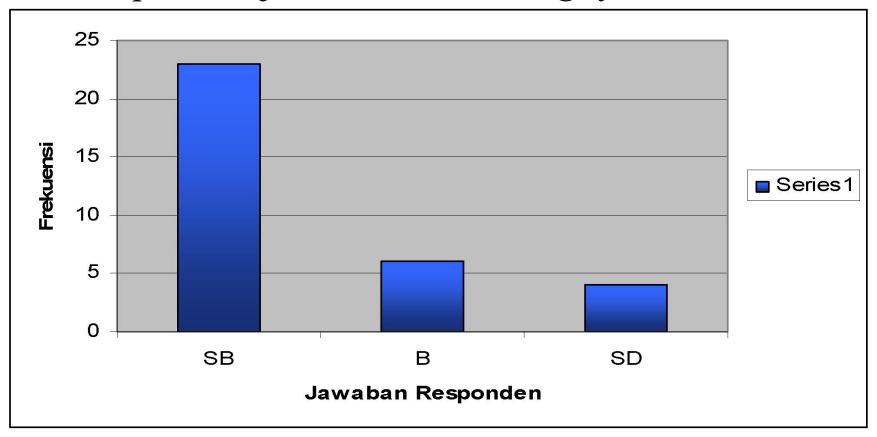

Grafik 3. Dosen micro teaching Dalam Mengevaluasi pembelajaran

4. Mahasiswa Melaksanakan Pembelajaran Micro teaching

Sesuai dengan hasil penelitian yang dilakukan maka data tersebut di kelompokan dan dimasukan kedalam sebuah tabel distribusi frekuensi yang dibagi dalam tiga alternative jawaban yaitu sangat setuju (SS), setuju (S) ragu-ragu (RR). Untuk lebih jelasnya dapat di lihat pada tabel di bawah ini:

Tabel 9. Tabel Distribusi Mahasiswa Melaksanakan Pembelajaran Micro teaching

\begin{tabular}{ccccccccc}
\hline No. & \multicolumn{2}{c}{ Sangat Setuju } & \multicolumn{2}{c}{ Ragu-Ragu } & \multicolumn{2}{c}{ Tidak Setuju } & \multicolumn{2}{c}{ Jumlah } \\
Item. & F & $\%$ & F & $\%$ & F & $\%$ & F & $\%$ \\
\hline 24. & 26 & 78.8 & 7 & 21.2 & - & - & 33 & 100 \\
25. & 28 & 84.8 & 5 & 15.2 & - & - & 33 & 100 \\
26. & 30 & 90.9 & 3 & 9.09 & - & - & 33 & 100 \\
27. & 26 & 78.8 & 7 & 21.2 & - & - & 33 & 100 \\
28. & 25 & 75.8 & 8 & 24.2 & - & - & 33 & 100 \\
29. & 28 & 84.8 & 4 & 12.1 & 1 & 3.03 & 33 & 100 \\
$\Sigma$ & 163 & 82.32 & 34 & 17.17 & 1 & 0.51 & 198 & 100 \\
\hline
\end{tabular}

Berdasarkan data responden yang telah dimasukan kedalam tabel frekuensi diatas maka diperoleh, sebanyak 26 orang atau 82,32\% sangat setuju, sehingga dikualisifikasikan 82,32\% mahasiswa sangat baik dalam melaksanakan penbelajaran micro teaching, sebanyak 6 orang atau $17,17 \%$ setuju sehingga dapat dikualisifikasikan mahasiswa baik dalam melaksanakan micro teaching, sebanyak 1 orang atau $0,50 \%$ ragu- ragu dan dapat dikualisifikasikan bahwa jumlah tersebut memiliki nilai sedang.

Hasil yang telah diperoleh dapat dimasukan kedalam tabel distribusi frekuensi dikualisifikasikan kedalam tiga alternative jawaban untuk didapat kesimpulan tentang bagaimana pelaksanaan pembelajaran micro teaching. Untuk lebih jelasnya dapat dilihat dalam tabel berikut ini.

Tabel 10. klasifikasi Mahasiswa Melaksanakan Pembelajaran Micro teaching 


\begin{tabular}{cccc}
\hline No & Jawaban & Jumlah & Persentase(\%) \\
\hline 1 & Sangat baik(SB) & 26 & 82,32 \\
2 & Baik(B) & 6 & 17,17 \\
3 & Sedang(SD) & 1 & 0,50 \\
& Jumlah & 33 & 100 \\
\hline
\end{tabular}

Tabel tersebut digunakan untuk membuat grafik histogram mengenai bagaimana pelaksanakan micro teaching, yaitu:

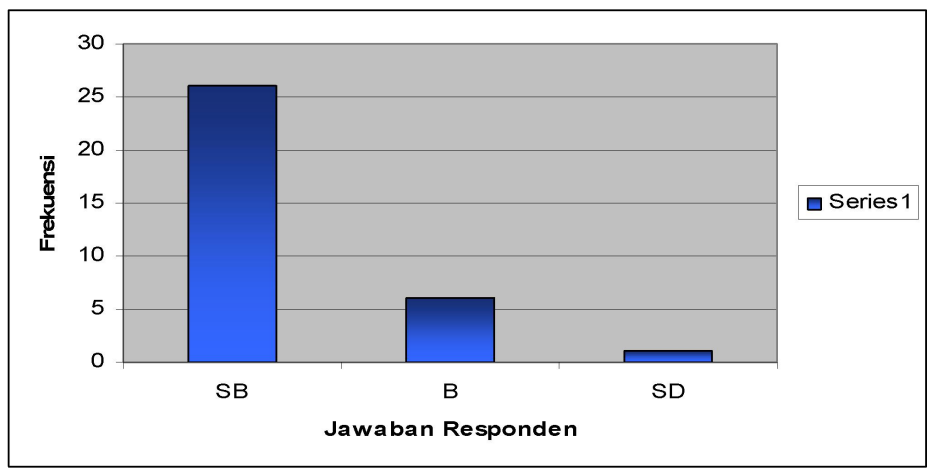

Grafik 4. Mahasiswa Melaksanakan Pembelajaran Micro teaching

5. Peranan Micro teaching Terhadap PLK.

Sesuai dengan hasil penelitian yang dilakukan maka data tersebut dikelompokan dan dimasukan kedalam sebuah tabel distribusi frekuensi yang dibagi dalam tiga alternatif jawaban yaitu sangat setuju (SS), setuju (S), ragu-ragu (RR). Untuk lebih jelasnya dapat dilihat dalam tabel distribusi.

\begin{tabular}{ccccccccc}
\multicolumn{2}{c}{ Tabel 11. Tabel Distribusi Frekuesi Perana Micro teaching Terhadap PLK } \\
$\begin{array}{c}\text { No. } \\
\text { Item. }\end{array}$ & \multicolumn{2}{c}{ Sangat } & Setuju & \multicolumn{3}{c}{ Ragu-Ragu } & \multicolumn{3}{c}{ Tidak Setuju } & \multicolumn{3}{c}{ Jumlah } \\
Ite & F & $\%$ & F & $\%$ & F & $\%$ \\
\hline 30. & 31 & 93.9 & 2 & 6.06 & - & - & 33 & 100 \\
31. & 29 & 87.9 & 3 & 9.09 & 1 & 3.03 & 33 & 100 \\
32. & 23 & 69.7 & 9 & 27.3 & 1 & 3.03 & 33 & 100 \\
33. & 29 & 87.9 & 2 & 6.06 & 2 & 6.06 & 33 & 100 \\
34. & 28 & 84.8 & 2 & 6.06 & 3 & 9.09 & 33 & 100 \\
35. & 30 & 90.9 & 3 & 9.09 & - & - & 33 & 100 \\
36. & 30 & 90.9 & 3 & 9.09 & - & - & 33 & 100 \\
37. & 33 & 100 & - & - & - & - & 33 & 100 \\
38. & 33 & 100 & - & - & - & - & 33 & 100 \\
$\Sigma$ & 266 & 89.6 & 24 & 8.08 & 7 & 2.36 & 297 & 100 \\
\hline
\end{tabular}

Berdasarkan data responden yang telah dikelompokan dan dimasukan kedalam tabel distribusi frekuensi, maka dapat di peroleh sebanyak 27 orang atau $89,56 \%$ sangat setuju,sehingga dikualisifikasikan bahwa $89,56 \%$ mahasiswa mengakui peranan micro teaching terhadap PLK sangat baik, sebanyak 4 orang atau $8,08 \%$ setuju dan dapat dikualisifikasikan bahwa $8,08 \%$ mahasiswa mengakui peranan micro teaching baik terhadap PLK, sebanyak 2 orang atau 2,36\% ragu-ragu dan dapat dikualisifikasikan bahwa 2,36\% mahasiswa beranggapan sedang terhadap peranan micro teaching untuk pelaksanaan PLK. Hasil yang telah didapat tersebut langsung dikualisifikasikan kedalam tiga kelompok jawaban dan dimasukan kedalam tabel. Untuk lebih jelasnya dapat dilihat pada tabel dibawah ini.

Tabel 12. Peranan Micro teaching Terhadap Pelaksanaan PLK 
Sport Science: Jurnal Sain Olahraga dan Pendidikan Jasmani ISSN 114-562X (Cetak), ISSN XXXX-XXXX(Online)

http://sportscience.ppj.unp.ac.id/index.php/jss/index

\begin{tabular}{cccc}
\hline No & Jawaban & Jumlah & Persentase(\%) \\
\hline 1 & Sangat baik(SB) & 27 & 89,56 \\
2 & Baik(B) & 4 & 8,08 \\
3 & Sedang(SD) & 2 & 2,36 \\
& Jumlah & 33 & 100 \\
\hline
\end{tabular}

Tabel tersebut digunakan untuk membuat grafik histogram mengenai peranan micro teaching terhadap PLK yaitu:

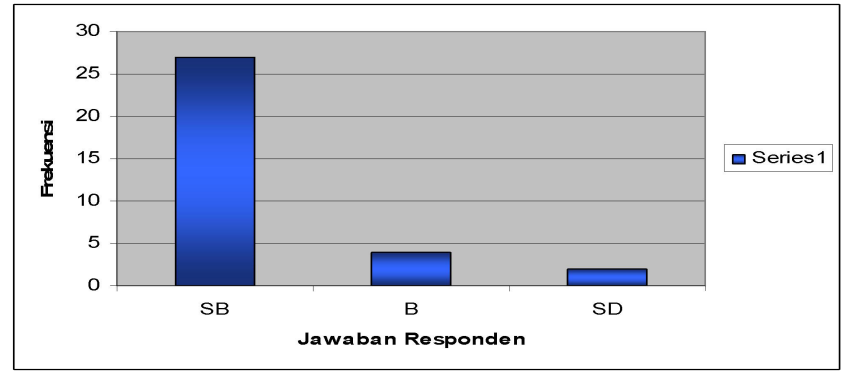

Grafik 5. Peranan Micro teaching Terhadap PLK.

6. Secara Keseluruhan Peranan mata Kuliah Micro teaching Terhadap Pelaksanaan PLK.

Sesuai dengan hasil penelitian yang diperoleh, maka berdasarkan tabel - tabel distribusi di atas dapat di peroleh secara keseluruhan peranan mata kuliah micro teaching terhadap pelaksanaan praktek lapangan kependidikan. Hasil tersebut dikualisifikasikan sehingga menghasilkan 26 orang atau sebanyak $82,22 \%$ mahasiswa mengakui peranan micro teaching sangat baik terhadap pelaksanaan PLK, 5 orang atau sebanyak $13 \%$ mahasiswa mengakui peranan micro teaching baik terhadap pelaksanaan PLK, 2 orang atau sebanyak 4,78\% mahasiswa mengakui peranan micro teaching sedang terhadap pelaksanaan PLK. Untuk lebih jelasnya dapat dilihat pada tabel dibawah ini.

\begin{tabular}{|c|c|c|c|}
\hline No & Jawaban & Jumlah & Persentase $(\%)$ \\
\hline 1 & Sangat baik(SB) & 26 & 82,22 \\
\hline 2 & Baik(B) & 5 & 13 \\
\hline \multirow[t]{2}{*}{3} & Sedang(SD) & 2 & 4,78 \\
\hline & Jumlah & 33 & 100 \\
\hline
\end{tabular}

Tabel diatas digunakan untuk membuat grafik histogram peranan mata kuliah micro teaching terhadap pelaksanaan PLK.

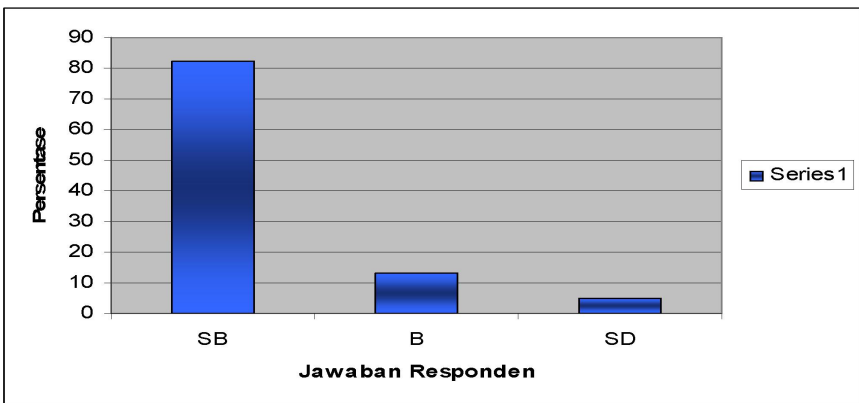

Grafik 6. Peranan Mata Kuliah Micro teaching

Terhadap Pelaksanaan PLK

Berdasarkan uraian di atas, dalam bagian ini akan diadakan pengolahan data guna menjawab pertanyaan penelitian yang diajukan, yaitu bagaimana peranan mata kuliah micro teaching terhadap 
pelaksanaan PLK. Berdasarkan temuan dalam hasil penelitian yang dibagi atas lima sub variabel tesebut didapatkan hasil sebagai berikut:

1. Peranan Micro teaching Dilihat Dari Dosen Menyampaikan Materi.

Dari 33 responden terhadap delapan butir pertanyaan tentang dosen menyampaikan materi, maka 27 orang atau $85,23 \%$ menyatakan sangat baik, sebanyak 5 orang atau $12,12 \%$ menyatakan baik, sebanyak 1 orang atau 2,65\% menyatakan sedang. Dari data tersebut menyatakan bahwa peranan micro teaching di lihat dari dosen menyampaikan materi mempunyai tingkatan baik

2. Peranan Micro teaching Dilihat Dari Dosen Membimbing Dalam Pelaksanaan Perkuliahan Micro teaching.

Dari 33 responden terhadap lima butir pertanyaan tentang dosen micro teaching membimbing dalam pelaksanaan perkuliahan micro teaching maka sebanyak 25 orang atau $81,21 \%$ menyatakn sangat baik, 6 orang atau 15,76\% menyatakan baik, 2 orang atau 3,03\% menyatakan sedang. Dari data tersebut dapat disimpulakn bahwa dosen micro teaching dalam membimbing pelaksanaan perkuliahan micro teaching memiliki tingkatan sangat baik.

3. Peranan micro teaching di lijat dari dosen mengevaluasi hasil pembelajaran micro teaching

Dari 33 responden terhadap 10 butir pertanyaan tentang dosen mengevaluasi hasil pembelajaran micro teaching, maka diperoleh sebanyak 23 orang atau $73,64 \%$ menyatakan sangat baik, 6 orang atau $14,24 \%$ menyatakan baik, 4 orang atau $12,12 \%$ menyatakan sedang. Dari data tersebut menunjukkan bahwa dosen mengevaluasi hasil pembelajaran micro teaching mempunyai tingkatan sangat baik.

4. Peranan micro teaching di lihat dari bagaimana mahasiswa melaksanakan pembelajaran micro teaching

Dari 33 responden terhadap enam butir pertanyaan tentang bagaimana mahasiswa melaksanakan pembelajaran micro teaching di peroleh sebanyak 26 orang atau $82,32 \%$ menyatakan sangat baik, 6 orang atau $17,17 \%$ menyatakan baik, 1 orang atau $0,50 \%$ menyatakan sedang. Dari data tersebut menunjukkan bahwa mahasiswa dalam melaksanakan pembelajaran micro teaching mempunyai tingkatan baik.

5. peranan micro teaching terhadap pelaksanaan PLK

Dari 33 responden terhadap sembilan butir pertanyaan tentang bagaimana peranan micro teaching terhadap pelaksanaan PLK, maka di peroleh 27 orang atau 89,56\% manyatakan sangat baik 4 orang atau $8,08 \%$ menyatakan baik, dua orang atau 2,36 menyatakan sedang. Dari data tersebut menunjukkan bahwa peranan micro teaching terhadap pelaksanan PLK mempunyai tingkatan yang sangat baik.

\section{Pembahasan}

Dalam buku UU RI No 14 Tahun 2005 tentang guru dan dosen, yang dimaksud dengan dosen adalah" pendidik yang profesional dan ilmuan dengan tugas utama mentransformasikan, mengembangkan, dan menyebarluaskan ilmu pengetahuan, teknologi dan seni melalui pendidikan, penelitian, dan pengabdian kepada masyarakat". Berdasarkan pengertian di atas, dosen memang harus benar-benar membimbing mahasiswa supaya mahasiswa lebih tahu dan mendalami minat dan bakatnya untuk di kembangkan menjadi suatu keterampilan yang nantinya akan berguna bagi mahasiswa, sehingga dalam suatu perguruan tinggi akan menghasilkan lulusan mahasiswa yang profesional di bidangnya yang mampu bersosialisasi dengan masyarakat serta menerapkan ilmu yang telah di dapat selama di kampus untuk diabdikan pada masyarakat.

Dalam penelitian ini pelaksanaan micro teaching di lihat dari dosen dalam menyampaikan materi sudah dapat dipahami dan dimengerti oleh mahasiswa, bimbingan yang di lakukan oleh dosen micro teachingjuga sudah dilaksanakan sebagaimana yang diinginkan oleh mahasiswa, ini bisa terlihat pada saat perkuliahan berlangsung, mahasiswa yang tampil menjadi guru diberi saran dan kritik untuk 
Sport Science: Jurnal Sain Olahraga dan Pendidikan Jasmani ISSN 114-562X (Cetak), ISSN XXXX-XXXX(Online)

http://sportscience.ppj.unp.ac.id/index.php/jss/index

kesempurnaan penampilan mahasiswa, begitu juga dalam mengevaluasi pembelajaran micro teaching, dosen sudah objektif dalam nenilai mahasiswa yang melaksanakan mocro teaching.

Pengajaran micro teching merupakan salah satu cara latihan praktek mengajar yang di lakukan dalam proses belajar mengajar yang dimicrokan untuk membentuk atau mengembangkan keterampilan mengajar, karena situasi mengajar itu sengaja didesain sedemikian rupa sehingga dapat dikontrol, maka pembentukan keterampilan baru atau pembaharuan suatu keterampilan mengajar dapat di lakukan secara terisolasi, maka melalui pengajaran micro calon guru dapat berlatih berbagai keterampilan mengajar dalam keadaan terkontrol untuk meningkatkan kompetensinya.

Mahasiswa yang tampil menjadi guru akan dinilai oleh dosen micro teaching dan mahasiswa yang menjadi peserta didiknya, apabila dalam tampil tersebut mahasiswa kurang baik maka akan diberi saran dan kritik dari tim penilai yaitu dosen dan mahasiswa yang menjadi siswa, kemudian tampil kembali untuk kesmpurnaan, sehingga pada saat mahasiswa tampil menjadi guru di sekolah latihan, mahasiswa akan mampu menjadi guru yang sebenarnya, bukan lagi guru yang asal-asalan saja mengajarkan materi pada peserta didiknya di sekolah latihan dan dalam penelitian mahasiswa sudah melaksanakan dengan baik pelaksanan micri teaching.

Micro teaching yang telah dilaksanakan mahasiswa di bangku perkuliahan, akan diterapkan di lapangan, pada saat mahasiswa praktek lapangan kependidikan, karena materi-materi dalam perkuliahan micro teaching mengarah kepada bagaimana cara seorang calon guru mengajar peserta didiknya, mulai dari membuka dan menutup pelajaran, menjelaskan materi, pengelolaan kelas, memodifikasi alat, dan mengevaluasi hasil belajar siswa.

Dengan demikian micro teaching ini dapat membekali mahasiswa agar dapat membuat dan merumuskan apa-apa saja yang dibutuhkan seorang guru dalam mengajar. Karena nanti dalam pengabdian sebagai Sarjana Pendidikan dijurusan Pendidikan Olahraga harus benar-benar memberikan dampak kreativitas terhadap proses belajar dan mengajar yang baru atau terbaharui. Hal ini senada menurut (Asnaldi, 2008) "Kreatifitas merupakan ungkapan unik dari seluruh pribadi sebagai hasil interaksi individu, perasaan, sikap dan perilakunya". Dalam penelitian ini mahasiswa mengatakan bahwa micro teaching memang sangat berperan sekali dalam pelaksanaan PLK di sekolah latihan.

Karena mahasiswa merasa sudah punya modal dasar untuk mengajar di sekolah latihan, dengan mempelajari micro teaching, materi-materi yang diajarkan pada micro teaching dirasakan dibutuhkan oleh mahasiswa yang akan melaksanakan PLK. Dengan demikian setelah dilakukan analisis dari data-data yang tercantum di tabel-tabel frekuensi di atas maka diperoleh hasilnya serta dapat disimpulkan yaitu peranan dosen dalam menyampaikan materi, membimbing,serta mengevaluasi pembelajaran micro teaching adalah baik, dan mahasiswa melakukan pelaksanaan micro teaching baik, serta mahasiswa menyatakan baik peranannya terhadap pelaksanaan PLK.

\section{KESIMPULAN}

Berdasarkan hasil penelitian di atas maka dapat disimpulkan bahwa: Pelaksanaan micro teaching yang dilaksanakan mahasiswa telah baik dan dapat dipahami serta dimengerti oleh mahasiswa, dan bimbingan dari dosen micro teaching juga telah dilaksanakan sebagaimana mestinya. Micro teaching yang dilaksanakan mahasiswa benar-benar dirasakan manfaatnya pada saat melaksanakan PLK di sekolah latihan.Hasil penelitian disarankan beberapa hal sebagai berikut: Diharapkan kepada dosen micro teaching, untuk lebih meningkatkan peranannya dalam membimbing mahasiswa yang melaksanakan pengajaran micro, supaya mhasiswa lebih mantap bila tampil menjadi guru pada saat praktek kependidikan di sekolah latihan.

Diharapkan kepada mahasiswa yang mengikuti perkuliahan micro teaching, supaya benarbenar melaksanakannya, karena mata kuliah micro teaching sangat berperan dan membantu sekali pada saat tampil menjadi guru disekolah latihan. Mahasiswa yang akan melaksanakan praktek lapangan kependidikan, harus mengambil mata kuliah micro teaching, yang telah dijelaskan pada buku 
pedoman akademik, karena pada micro teaching, materi yang dipelajari adalah materi-materi yang mengarahkan mahasiswa bagaimana tampil menjadi guru yang profesional dalam proses belajar mengajar. Dalam melaksanakan micro teaching, mahasiswa dibagi beberapa kelompok, untuk tampil menjadi guru secara bergantian di dalam kelompoknya.

Diharapkan kepada ketua jurusan untuk memilih dan menentukan dosen micro teaching dan dosen pembimbing PLK yang sesuai dengan disiplin ilmunya. Diharapkan pada Unit Pengalaman Praktek Lapangan untuk lebih berperan aktif dalam mengkoordinator mahasiswa yang melaksanakan PLK.

\section{DAFTAR RUJUKAN}

Asnaldi, A. (2008). Hakekat Kreativitas. In BlogSpot (Issue Hurlock 1978, pp. 1-2). BlogSpot. https://artikel-pendidikan.blogspot.com/search?updated-max=2008-02-08T19:51:0008:00\&max-results $=1 \&$ start $=4 \&$ by-date $=$ false

Asnaldi, A. (2015). Profesionalisme Guru Pendidikan Jasmani di Sekolah Dasar. Sport Science, 23(28), $1-15$.

Arikunto, Suharsimi. 1990. Prosedur Penelitian: Suatu pendekatan Praktis. Jakarta: Rineka Cipta.

Gaffar, Muhammad Fakri. 1987. Perencanaan Pendidikan Teori dan Metodologi. Jakarta: Dirjen Dikti Depdikbud.

IKIP. 1999. Buku pedoman Akademik. IKIP. Padang

Joni, T.Raka. 1980. Pengembanagan Kurikulum IKIP Suatu Kasus Pendidikan Guru Berdasarkan Kompetensi. Jakarta: Depdikbud P3G.

Sudjana. 1989. Metode Statistik. Bandung :Tarsito

S.L. La Sulo. 1984. Pengajaran Mikro. Jakarta: Depdikbud.

W.S. Winkel. 1984. Psikologi Belajar. Jakarta: Grasindo.

Yandianto. 2003. Kamus Umum Bahasa Indonesia. M2s Bandung : Bandung.

Yusuf, Muri. 2002. Buku Pedoman Akademik UNP. UNP Padang: Padang.

UPPL. 2005. Buku Pedoman Pengalaman Praktek Lapangan. UNP Padang: Padang.

UPPL. 2005. Buku Pedoman Mikro. UNP Padang: Padang.

UU RI No 20. 2003. Tentang Sistem Pendidikan. Jakarta: Kaldera Pustaka Nusantara

UU RI No 14. 2005. Tentang Guru dan Dosen. Jakarta: Kaldera Puastaka Nusantara. 